\title{
An Appraisal of Qualifying Role of Hydraulic Heritage Systems; \\ A Case Study of Qanat in the Central Iran
}

\author{
Mehdi F. Harandi ${ }^{1}$ \\ Marc J. de Vries ${ }^{2}$
}

\section{$\underline{\text { Abstract }}$}

Hydraulic heritage systems, both underground and exposed, have been known to be sustainable for millennia. Persian and also Roman aqueducts are examples of such hydrosystems. Their values are often overlooked but they have undeniable advantages: they have functional interconnectedness with their surrounding society and ecology, which sometimes leads to revitalization plans. By using the notion 'qualifying role', this paper will raise questions concerning the disregarded functions and early and historical positions of hydraulic heritage systems. This article illustrates the qualifying role of Qanats in urban drainage by describing the skill in their planning and construction. This is shown by a problematic case study in Iran, where the construction of a drainage system modelled on bygone Qanat's techniques resulted in a dramatic drawdown in the water level of the area soon after construction.

Keywords: aqueduct, hydraulic heritage system, underground water supply network, technological development, Qanat technology.

\footnotetext{
${ }^{1}$ Department of Hydraulic Engineering, Delft University of Technology, Delft, The Netherlands. e-mail: m.fasihiharandi @ tudelft.nl ${ }^{2}$ Department of Philosophy, Delft University of Technology, Delft, The Netherlands
} 


\section{Introduction}

Hydraulic heritage systems, such as Persian underground 'water supply networks', have been known to be sustainable (English, 1998) for millennia. For many years these water supply systems have been facing diverse and adverse contradictions mostly of a 'utilitarian nature' (Martínez-Santos and Martínez-Alfaro, 2014) of engineering heritage linked to modernism. They have by far been overtaken by engineering infrastructure and were deemed as a hindrance for modern technological development. Although there are exceptions, quite a few of arid and semi-arid areas are still dependent on hydraulic heritages. Among them are Qanats, which as a socio-technical system tend to have a 'functional interconnectedness' interactively with the surrounding society and ecology. However, these areas are accommodating more people than they can sustain (Mays, 2007), and increasingly such less sustainable urbanization growth is manipulating this connection explicitly or tacitly.

There are floods of studies that have identified the worldwide importance of hydraulic heritage systems. Lofrano et al. (2013) illustrate Qanats in Palermo as elements that made Bal'harm (the city's name in the Middle Ages) 'a flourishing town'. Voudouris et al. (2013) link the ancient Greeks' water management skills to 'aqueduct-like' Qanat technology that was developed by Persians in the middle of the $1^{\text {st }}$ millennium BC. There are concerns about dealing with Qanats, as Motiee et al. (2006) highlight notions of 'traditional water management', rehabilitation and the renovation of Qanats and Qanats' rights, particularly for large urban areas. Hosseini et al. (2010) and Martínez-Santos and Martínez-Alfaro (2014) have also documented the effects of urban sprawl upon Qanats in the North-East of Iran and Madrid, respectively. In the present article, we will try to raise questions concerning the disregarded functions and early and historical positions of hydraulic heritages by looking at Qanats. This paper focuses on the issues surrounding the roles of Qanats in one of the Zayandeh-Rud River regions in the vast province of Isfahan in Iran. We will contribute to 
these scientific approaches by notion of qualifying role to answer the leading question in the paper: the fact that the role of Qanats should be considered during the processes of development because of their qualifying role. By qualifying role we mean, Qanat still deserves itself to participate in hydrosystems development processes.

The Qanats' qualifying role raises questions concerning the disregarded functions and early and historical positions of these hydraulic heritage systems. This is shown by a problematic case study in Riz, a suburb of the historical and industrial city of Isfahan, where the construction of a drainage system modelled on Qanats' bygone techniques resulted in a dramatic drawdown in the water level of the area soon after construction. We will first describe the history and technology of Qanats in Persia/Iran from a bird's eye view. Then we will describe the problematic side effects of the development of the city on Qanats and describe how one of these externalities was tackled by turning back to a more traditional approach, Qanat revitalization. The paper will attempt to present the case according to interviews with people living in the area, an appraisal of the last vestiges of the old Qanats, survey of the data from engineering literatures (i.e. reports and drawings on the sewerage and water distribution systems), as well as procedures and practices to support different affirmations of using a revitalized Qanat as a drainage system for the city.

\section{Qanat technology and its mutual interaction with modernization in Iran}

\subsection{Technical function}

The term Qanat comes from a 'Semitic word meaning 'to dig', (Stiros, 2006) and over the centuries, this technology was transferred to other civilizations and become known by different names such as: Hydragogeion, e.g. aqueduct (from the words hydro = water and agogos $=$ conduit, Greek), Karez, Kariz, Kahriz, (which are derived from the Persian the word Kariz), Foggaras, Fughara, Khettras (North Africa and Spain) and the Chinese definition of 
kan'erjing (Hu et al. 2012). Various definitions of Qanat are also listed in Voudouris et al. (2013, p. 1341). Apart from Persian altitude-based aqueducts such as what we see in Chogha Zanbil, the elaborate Qanat system was 'arguably invented' (De Feo et al., 2013) and 'practiced' (Pazwash, 1983) in Persia some centuries B.C. and was gradually introduced to Egypt, India, China and Spain in 500 B.C. Stiros (2006) represents Qanat's as benchmark in the civilization for many arid areas' as Pazwash (1983) has called Qanats 'the most extraordinary works' of the Persian people for collecting water. Technically speaking 'qanats are gently sloping tunnels used to tap and convey shallow groundwater' (Martínez-Santos and Martínez-Alfaro, 2014) by gravity (Wulff, 1968). They are cleverly hidden and carry the invaluable water in the deserts hundreds of miles away to reach to the destinations. For practical purposes, they are best described as 'horizontal wells' (Cressey, 1958). In terms of 'structure', a Qanat consists of an inclined conduit (traditionally named, Kureh كوره), crossed with many vertical ventilation shafts (traditionally named, Mileh ميله) and connected to the ground surface. The shafts also serve purposes such as hauling up the excavated materials, indicating the direction of the tunnel during the construction phase and performing maintenance during the exploitation phase (see Fig. 1). The inner radius of the tunnel is reinforced by earthenware hoops (traditionally named Kaval and Goom كَول و كَوم). Qanats in terms of a 'pattern' can be divided into mountainous and flatland types, of which the latter are mostly branched from rivers. Qanat technology has many similarities with tunnelling but crucially needs a basic knowledge of groundwater fluxes in addition to an accurate surveying, based on astronomy and the precautionary principle of safety related to ventilation. As its main function a Qanat conveys water from upstream through downstream by gravity. Depending on their patterns, Qanats capture groundwater from rivers or alluvial fans by obtaining a 'preferential drainage path' (Martínez-Santos and Martínez-Alfaro, 2014) (i.e. tunnel or gallery) below the water table. Drainage as one of the Qanat's function is widely 
overlooked, alongside their other technical functions such as water supply, conveyance and distribution, a source of energy for water mills (Hussain et al., 2008 and Jomehpour, 2009), soil salinity balancing and non-technical roles such as social partnerships. Jomehpour (2009) has also described these roles as a specific function of Qanats. The next sections will show how this technology can qualify as a method for resolving drainage issues. Before addressing the method, we probe the mutual interactions of Qanats as a socio-technical hydrosystem with urbanization growth and Iran's modernization era in the recent past.

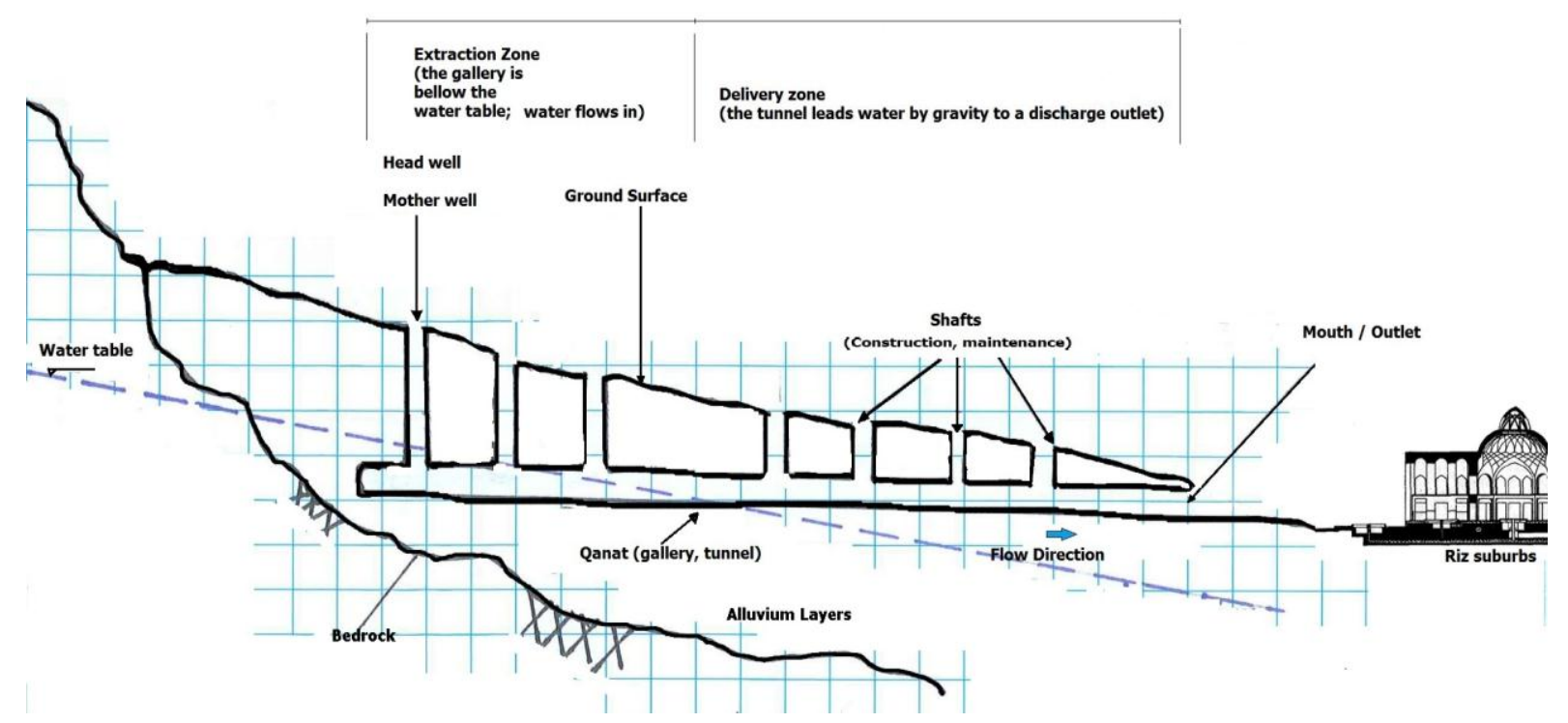

Figure 1: A Qanat scheme (Descriptions are derived from Martínez-Santos and Martínez-Alfaro, 2014)

\subsection{Iran's mode of development and Qanats}

Recently a narrower, more modernist approach has eventually led to serious problems in the functioning of the Qanats. This approach originated in the early 1960s and has been strengthened in recent decades. It predominately had root in 'a modernist ethos that considered traditional village irrigation [systems] as primitive' (Molle and Mamanpoush, 2012), and increased the pace of Iran's hydro-oriented so-called development. This was fostered by a copied plan to develop agriculture as a backbone for large industrial development (Balali, 2011). Water-harnessing projects including the construction of 
reservoirs and digging wells to irrigate farmlands were at the centre of all these projects (Ettehad, 2010), which were 'ill-conceived and ill-suited to Iranian conditions and needs' (Afshar, 1981).

Therefore then there was a continual modern Western view in Iran's mode of development, which gradually became a strong conviction, to look at 'the natural environment as the object to be conquered' (Wang and Zhu, 2012). It certainly deems the Qanats' technology as a seeming hindrance for progress and outdated technology, has unintentionally marginalized, destroyed and dried up them, particularly those Qanats that adjoined cities (Jomehpour, 2009 and Hosseini et al., 2010). They were dramatically replaced by more productive but less sustainable engineering heritage systems (i.e. dams and deep wells) (Afshar, 1981 and English, 1998). However, the farmers and city dwellers who had initially resisted finally bowed to these practices and their transient/short-term and unsustainable benefits. Molle et al. (2004) explain the story of the unfettered development in the case of wells; 'the development of wells in the villages competed with, and impacted on, both local Qanats that supply the same communities and downstream ones, because of the resulting critical uptake of groundwater'. Molle and Mamanpoush (2012) also denounce such development and its subsequent diversifying of the sources of water that tends to override the Qanats' rights. As they hold, freeholders got into the 'business of well digging despite reservations and awareness that Qanats might be impacted', and intuitively, massive drilling in aquifers caused overexploitation of groundwater. What we see now is that this unbridled well drilling has exhausted aquifers and caused the abolition of the historical investments and rights vested in the Qanats that had supplied water to towns and villages for millennia.

These measures often threatened the performances of Qanats, including water conveyance, recharge and drainage functionality (De Feo et al., 2013 and English, 1998), and Qanats could no longer support the regions' rapidly burgeoning numbers of people (France, 2007). 
Imperceptibly, these ancient assets were wasted; whereas in 1968, more than 75 per cent of the water used in Iran was provided by Qanats, now a large proportion of the Qanats have been put out of operation (McLachlan (1988) and Beaumont (1989) estimate the number of Qanats in Iran between 30,000 and 50,000 whereas Karimi (2003) states this number had fallen to 27,481 by the year 1999.) and those remaining are struggling to function because of the tiny amount of remaining water.

\section{Characteristics, case description and problem background}

The vast city of Isfahan and its suburbs have been supplied from the Zayandeh-Rud River, a river that is $400 \mathrm{~km}$ long and has a basin area of $41,500 \mathrm{~km}^{2}$, and which flows from the Zagros mountains to the Gavkhuni swamp (listed under the Ramsar Convention) in the centre of Iran (Fig. 3). Two major characteristics in the case have highlighted the qualifying role of the Qanat. Firstly, the mountainous part of the basin culminates at around 2,300 $\mathrm{m}$ but the case study area, Lenjan District, Riz City - which after industrialization was named 'ZarrinShahr', which means Golden City - stands at a lower altitude, at around 1,550 m. Riz City is located on the relatively flat alluvial plain adjacent to the river. The sedimentation of the Zayandeh-Rud River has had a significant effect on the formation of the current topographic features of this region. It is surrounded by mountains in the North East and the East on the one hand, and the Zayandeh-Rud River in the south on the other hand, and this causes groundwater flows to the region. This affects the city, which is irregularly inundated by both groundwater and runoff and the ensuing dire need for drainage. Secondly, Iran's central plateau as well as this area is classified in the semi-arid zone with minimal and improper distribution rainfall and periodic drought and paucity. 


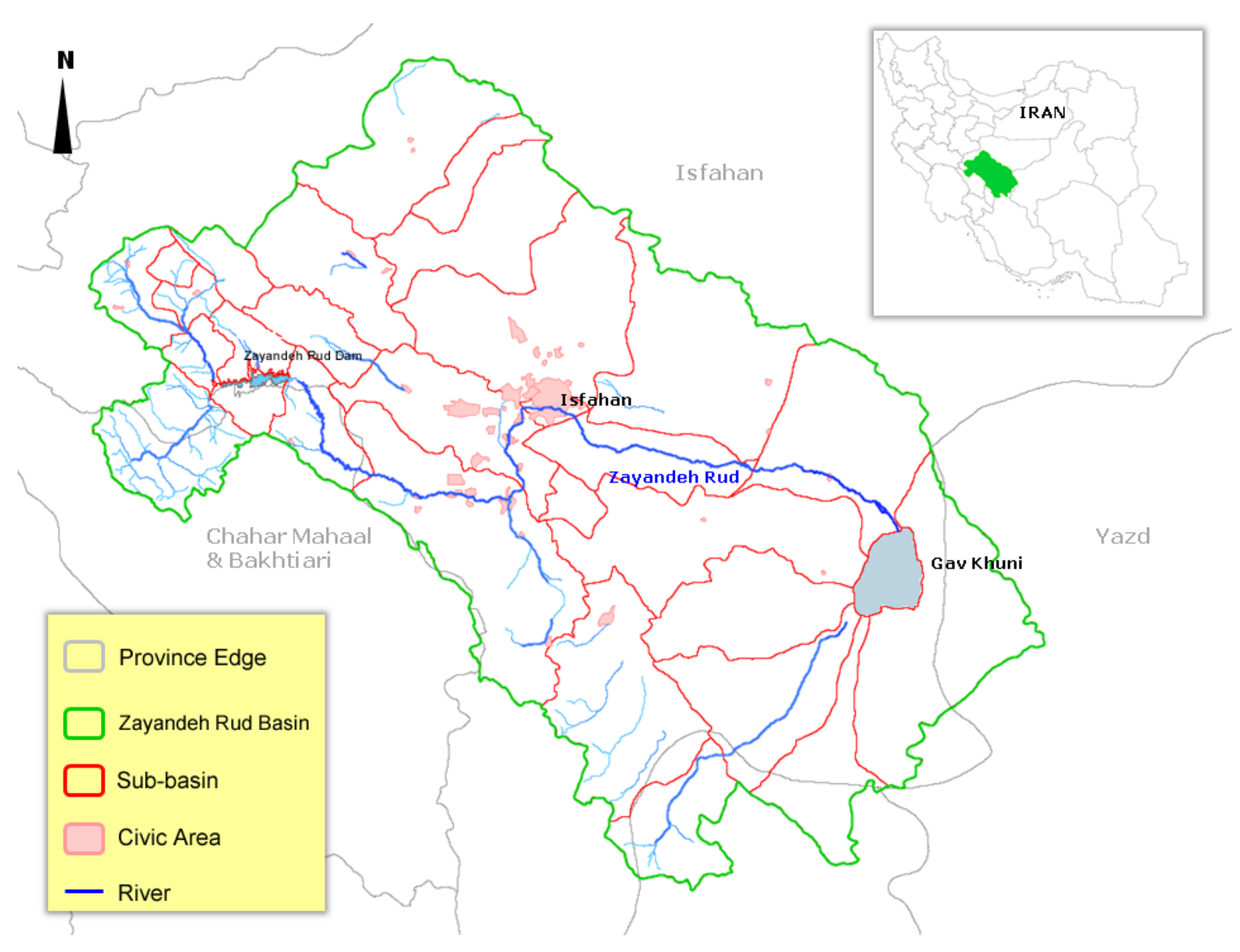

Figure 2: The Zayandeh-Rud basin (Harandi et al., 2014)

Extension of the city was performed in light of the river's resources. Due to rich farmland, at a regional level, and major industries such as steel, chemical and military, at a national level, this area is of importance. Nationally, these industries, which have been developed based on the Zayandeh-Rud River, boost the role of the region and have attracted population. Urbanization growth in this area, which was partly performed because of the river's resources, has firstly increased demand for projects related to facilities, and subsequently these projects have become a potential threat to Qanats. Because previously there were villages with flourishing farmlands relying on agribusiness, but now there are the city(ies) that are struggling with all the disadvantages of having two systems (cities attached to villages) mixed up and as a consequence the hydraulic heritage systems are threatened by such a mixed cityvillage system. However, as mentioned earlier, urban drainage is potentially a crucial issue in the case of runoff and high water tables and every year Riz City is faced with serious drainage 
problems; it is partly inundated and the groundwater bubbles up near settlements (Fig. 3b). Moreover, due to some areas with high bedrock and fine soil texture, drainage here is unavoidably required.

According to the Sheikh Bahai scroll - a 400-year-old ancient document of the water sharing of the Zayandeh-Rud River - the Lenjan and Alanjan districts had 10 of the 33 shares of the river (Hossaini, 2006; Pirpiran, 2007), and moreover the districts have been largely dependent on groundwater as well as numerous springs and Qanats (Molle and Mamanpoush, 2012). As mentioned earlier, in addition to water conveyance, Qanats can drain water from the aquifer toward their outlet and the Zayandeh-Rud valley is already used to exploit this advantage. Indeed, this highlights the role of Qanats in regulating hydrologic cycles and also in increasing the Zayandeh-Rud River flow with underground water flux. According to the local inhabitants, in the recent past, the Hosseinabad Qanat's task was partly to carry out the drainage of the farmlands (now the city) in addition to transferring and supplying farmland autonomously, efficiently and effectively with no externalities for the environment or society. Therefore the city district authority called experts to tackle the problems by close collaboration with all the stakeholders in the area. Habitual drainage and sewerage system ineffectiveness - in this particular case - has been frequently emphasized by various indications, such as water bubbling in the building, streets and sewerage manholes.

\section{Methodological approach, scheme and results}

Although there is no precise information on this, how long the Hosseinabad Qanat has been out of action, the imbalanced developments of Riz City as well as previous factors have all contributed to its destruction. These indications can be clearly seen in the construction of a sewerage system in the heavily urbanized parts and narrow streets of the city that cross over and are parallel with the Qanat's galleries and shafts. Many shafts of the Qanat had been filled 
with sewerage trench debris over the years before starting this project. The planners portrayed the performance of the Hosseinabad Qanat as a whole normative system that could be the starting point of rectifying and resolving the issue. At the outset, an appraisal of the known remains was carried out, leading to an inventory of galleries, shafts (some of which are now sewerage manholes) and deposits. This was followed by a thorough mapping and a survey of all the existing reports, including physical descriptions of the sewerage system and underground water level metering, among other documents. In the study phase, the identified remains of the conduits and the evidence of damp, mould and condensation - which were a problem in- and outside the settlements - and also signs of groundwater that bubbles up near houses, all are the results of semi-structured interviews, as on-going interaction processes and informal conversations. Moreover, during the construction phase these site visits and interviews also represented how quickly the project proceeded when interviewees reported a one-meter drawdown decreasing in the water table in the basement of their homes and settlements. (Payandab Tavan, 2009).

The above methods identified the damaged sectors of the Qanat and also made it possible for engineers to find remains which were in good condition. Following the site visits (Fig. 4) and interviews, the engineers examined possible techniques for draining excess water in the district (Payandab Tavan, 2009) as well as drainage pipes and pump station(s). As a routine procedure in drainage projects, using a combination of buried pipes and pump-equipped drainage was proposed and evaluated as a serious alternative, but the advantages of the Qanat convinced the engineers to choose it over other alternative(s).

For designing a long-lasting system, five main engineering criteria were considered by the designers; the terrain changes, longitudinal profile of the conduit, normal water depth within the Qanat's gallery, maximum probable water table in the area due to backwater of the downstream farmlands' high water table and the height of the conduit. As such, the Qanat 
system was entirely divided into three sectors due to the construction limitations and mostly due to allocate an appropriate slope for the Qanat. Surveying showed there are considerable differences in the terrain - upstream to the downstream outlet about $1.3 \mathrm{~m}$ - and a conduit could be planned with a very steep slope which is appropriate for construction of such a sensitive hydrosystem. The slope is very important in the Qanat for two reasons: firstly to avoid sedimentation and degradation and secondly to keep the conduit and the study area safe enough from probable backwater of the downstream's farmlands (the Qanat's outlet). As the old Qanat's conduit for one of the three sectors was completely clogged and there was no affordable access to it - because the old path is beneath the foundation of the settlements - a new open-trench conduit (see the cross section in Fig.3) with a length of 800 meters and 0.001 slope was considered.
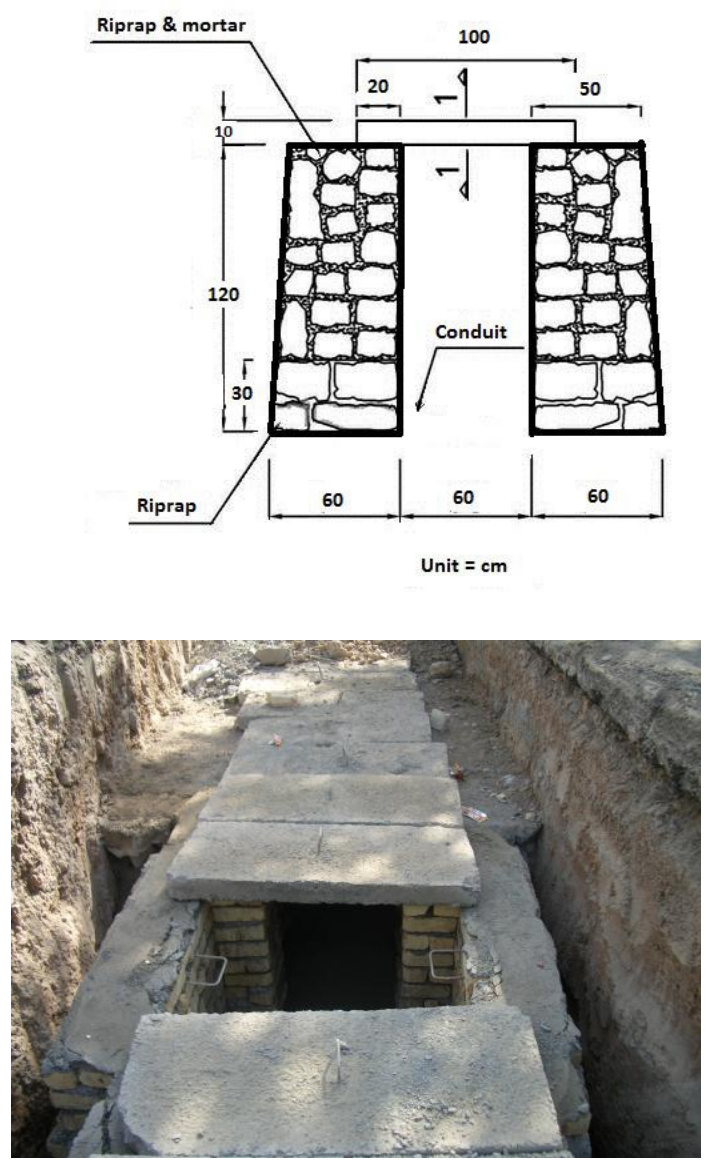

Figure 3: Typical cross section of the scheme, the concrete slabs (1-1) will be covered by aggregated soil. 
To check the system's flexibility, four scenarios for discharged drainage were examined. To some approximation, the calculations in Table 1 show that a ten-fold increase in drainage discharge would only cause a three-fold increase in the conduit's water level, which is extraordinary for a drainage system.

Table 1: Water depth calculations in the revitalized Qanat (different scenarios)

\begin{tabular}{|c|c|c|c|}
\hline $\begin{array}{c}\text { Calculated drainage } \\
\text { discharge }(\mathrm{CMS})\end{array}$ & $\begin{array}{c}\text { Manning's } \\
\text { Roughness }\end{array}$ & Conduit slope & \\
\hline 0.025 & 0.04 & 0.001 & 0.18 \\
\hline 0.050 & 0.04 & 0.001 & 0.35 \\
\hline 0.100 & 0.04 & 0.001 & 0.60 \\
\hline 0.200 & 0.04 & 0.001 & 1.10 \\
\hline
\end{tabular}

Accordingly, conduit stabilization by means of one of the Qanat's techniques was implemented. This technique is an important advantage of the Qanat system that uses a sequence of materials consisting of the riprap and mortar-riprap, in the both sides of the gallery. The riprap in the bottom drains water through the porous media and the saturated area into the conduit. Ripraps also perform as retaining wall. This technique has been 'borrowed' from Qanat technology to build a permeable (and in fact stable) retaining wall in the drain's galleries, using cost-effective and locally available materials. On the top of the riprap and beneath the slab (refer to Fig. 3), mortar-riprap functions as support for slab.

One of the main social applications of this Qanat was in supplying the water required to perform ablution (Wudu) in mosques. Previously, water was supplied by the Qanat. Figure 4 (left) shows the water tail in the wall of the outdated Qanat's outlet and the situation (before the revitalization) of the traditional ablution place where the Qanat is exposed. It was fully flooded by sullage. As can be seen in Figure 4 (right), the water tail in the same place shows that the revitalized Qanat has drained the excess water within the saturated soil. Thus the Qanat safely performs the function of drainage in different scenarios of groundwater 
uncertainty, and lowers the water table in different circumstances with a high radius of influence in such an unconfined aquifer.
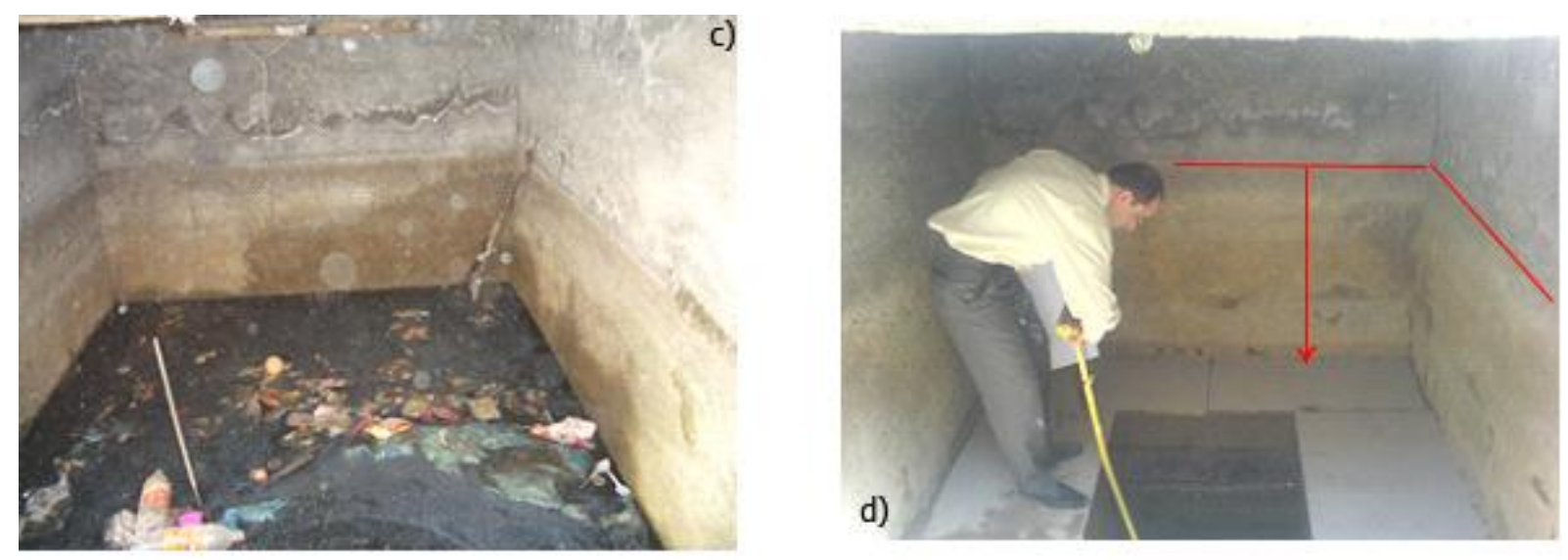

Figure 4: Qanat's outlet, before and a couple of days after revitalization.

\section{Discussions and conclusions}

We investigated the qualifying role of hydraulic heritage systems to tackle the issues of blind development. For this purpose a case study of a Qanat was examined to validate this argument. An urban drainage plan was modelled on Qanat construction skills and techniques to ensure the optimal long-term performance of the drainage system. Our case study placed a double emphasis on these questions: 'In our scientific and technical world, where water technology has developed based on a model of big infrastructure, water transfers, and inexhaustibility of the resource, does a place still exist for traditional technology in modern[ist] water management?' (Schneier-Madanes and Courel, 2010) and how can a return to the traditional approach with its inclusion of social values (Balali et al., 2011; Jomehpour 2009) be used to resolve the issues. Certainly, it would be no exaggeration to say that the efforts of renovation and rehabilitation of a Qanat have resolved the drainage issue in a city.

The concept of qualifying roles in hydraulic heritage systems calls for three sets of profound questions: the first - and perhaps most obvious one - is to understand the performances and mechanisms which tend to be associated with development projects. 
Secondly, a set of questions concerns the introduction of the early and historical rights of these systems, in our case Qanats. The third set that the article raises is how a simple look back into recent history can contribute to resolving current water-oriented problems. It is of great importance that this article made these questions explicit. And yet again, the article has reiterated that Qanats are impressive technical and engineering feats. However it has certainly elucidated repairing and maintaining existing hydraulic heritage is doable and feasible, but it seems to construct them today under appropriate working and safety standards would make them very difficult and expensive. Therefore long-term usage of Qanats in this way will present possibilities for combination of an overlooked technology with infrastructure and knowledge that is available nowadays. For instance, as the techniques and excavation technology of Qanats have gradually changed (Stiros, 2006), it might possibly be affordable now to apply new techniques of construction to effectively show the values of such systems. Namely, we suggest regarding the geotechnical aspects of Qanats using robots (Khorasan News, 2012) that they can perform maintenance more easily and more affordably. Also the usage of Tunnel Boring Machines (TBMs), specifically to be designed for Qantas compared with tunnelling standards - can facilitate the excavation work and shrink the investment and maintenance costs of Qanats.

This paper has also emphasised on social values and provide a naïve way of rethinking to policy-makers and engineers about to revise the water management strategies based on the sustainable and inherently dynamic rules of nature and 'historical water practices in the locality' (Dang et al., 2013). We have finally argued how engineering heritage systems can be built based on the commonalities of modern and traditional values. This contribution is a general criterion of hydraulic heritage systems as they always get along with nature and society. A Qanat in that sense, is very attuned with the hydrological cycle, geological formation and ecology as well as the societal values of the region in which it is laid out. As 
we see Qanat as a socio-technical system, our view is very near with conviction of about harmonization, reciprocal unity and reliance of man and nature on technological development, especially where they stress the local rationality of adjusting measures to natural and environmental conditions and the relationship between the 'parts' and the 'whole' Wang and Zhu, (2012), which can be clearly seen from the abovementioned function of Qanats. However this view of harmonization might be deemed impertinent to our account because it comes from a relatively different ideology, culture and background; here we only wanted to point out that it is similar in both contexts. The planning, calculating, construction and handling skills and knowledge of Qanats have harmoniously contributed to the development processes. Due to a holistic approach to development, the Qanat has arguably potential trends relevant to sustainability issues of the technology and can resolve part of the water-based issues in a sustainable way.

Without doubt, modernism-linked technological development has 'grown more varied and complex and has by far surpassed the ancient technological methods' (Wang and Zhu, 2012 p. 373); however, the human-technology-nature interconnectedness ought to be seriously considered and observed. We should definitely set the pace of progress within/between the parts (beings and technology) and the whole (nature, reality).

\section{$\underline{\text { Acknowledgement }}$}

The authors wish to thank the consulting engineering company Payandab Tavan in Iran for its invaluable funding support and are also grateful to anonymous reviewers.

\section{$\underline{\text { References: }}$}

Afshar, H., 1981 An assessment of agricultural development policies in Iran, World Development 9(11): 1097-1108. 
Balali, M.R., Keulartz, J., Korthals, M., 2011 Reflexive Land and Water Management in Iran: Linking Technology, Governance, and Culture, Part1: Land and Water Management Paradigms, Iranian Journal of Water Research In Agriculture 24(2):99-73.

Beaumont P., 1989 The Qanat: a means of water provision from groundwater sources. In: Qanat, kariz, and khattara, P. Beaumont, K. Borine, K. McLachlan (eds.). School of Oriental and African Studies, London, 13-31.

Cressey, G. B., 1958 Qanats, Karez, and Foggaras. Geographical Review, 48(1), 27-44.

Dang X., Webber M., Chen D. and Wang M., 2013 Evolution of Water Management in Shanxi and Shaanxi Provinces since the Ming and Qing Dynasties of China. Water, 5(2):643-658.

De Feo G., Angelakis A.N., Antoniou G.P., El-Gohary F., Haut B., Passchier C.W. and Zheng X.Y. 2013 Historical and Technical Notes on Aqueducts from Prehistoric to Medieval Times. Water, 5(4):1996-2025.

English P.W., 1998 Qanats and life worlds in Iranian plateau villages. Yale F. \& E.S. Bull. 103: $187-205$.

Ettehad E., 2010 Hydropolitics in Hirmand/Helmand international river basin and application of integrated water resources management. Master Thesis, Department of Urban and Rural Development, Swedish University of Agricultural Sciences.

France R.L., 2007 Handbook of Regenerative Landscape Design, CRC Press, ISBN: 978-14200-0873-9.

Harandi, M., S. Yarahmadian, Spehrifar M., van Gelder P., 2014 The dichotomous Markov process with nonparametric test application; a decision support method in long-term river 
behavioural analysis: the Zayandeh Rud River; a case study from central Iran. Stochastic Environmental Research and Risk Assessment, DOI 10.1007/s00477-014-0854-y.

Hossaini S.H., 2006 Ancient Water Management in the Zayandeh Rud River Basin, Iran. Working Paper. IWMI, Colombo. Draft Report.

Hosseini, S.A., Shahraki, S.Z., Farhudi R., Hosseini S. M., Salari M., Pourahmad A., 2010 Effect of urban sprawl on a traditional water system (qanat) in the City of Mashhad, NE Iran. Urban Water Journal, 7(5): 309-320.

Hu W., Zhang J. and Liu Y. 2012 The qanats of Xinjiang: historical development, characteristics and modern implications for environmental protection. Journal of Arid Land, 2012, 4(2): 211-220, DOI: 10.3724/SP.J.1227.2012.00211.

Hussain I., Abu-Rizaiza, O.S., Habib M.A.A., Ashfaq M., 2008 Revitalizing a traditional dryland water supply system: the karezes in Afghanistan, Iran, Pakistan and the Kingdom of Saudi Arabia. Water International, 33(3): 333-349.

Jomehpour M., 2009 Qanat irrigation systems as important and ingenious agricultural heritage: case study of the Qanats of Kashan, Iran. International Journal of Environmental Studies, 66:3, 297-315, DOI: 10.1080/00207230902752629.

Karimi S., 2003 Qanat, as the symbol of the native Iranians in water harvesting from ground water resources. In: Paper Presented to the $3^{\text {rd }}$ IWHA Conference in Alexandria, Egypt, 11-14 December.

Khorasan News, 2012. Qanat's Robot designed by Birjand University of Technology (in Persian). South Khorasan, 18087, http://www.khorasannews.com 
Lofrano G., Carotenuto M., Maffettone R., Todaro P., Sammataro S. and Kalavrouziotis I.K. 2013 Water Collection and Distribution Systems in the Palermo Plain during the Middle Ages. Water, 5(4):1662-1676.

Martínez-Santos, P., Martínez-Alfaro, P.E., 2014 A priori mapping of historical water-supply galleries based on archive records and sparse material remains. An application to the Amaniel qanat (Madrid, Spain), Cultural Heritage, DOI: 10.1016/j.culher.2013.12.003.

Mays L.W., 2007 Ancient urban water supply systems in arid and semi-arid regions, Paper presented at the International Symposium on New Directions in Urban Water Management, UNESCO Paris, 12-14 September.

McLachlan K., 1988 The Neglected Garden: The Politics and Ecology of Agriculture in Iran, LB. Tauris \& Co. Publishers, London.

Molle F., Mamanpoush A., 2012 Scale, governance and the management of river basins: A case study from central Iran. Geoforum 43(2): 285-294.

Molle F., Mamanpoush A, Miranzadeh M., 2004 Robbing Yadullah's water to irrigate Saeid's garden: Hydrology and water rights in a village of central Iran. Research Report 80. Colombo, Sri Lanka: International Water Management Institute.

Motiee H., McBean E., Semsar A., Gharabaghi B., Ghomashchi V., 2006 Assessment of the Contributions of Traditional Qanats in Sustainable Water Resources Management, International Journal of Water Resources Development, 22(4), 575-588, DOI: 10.1080/07900620600551304.

Payandab Tavan, Consultant Engineering Co. in Iran, 2009 Urban drainage studies of Hosseinabad Qanat's related basin, Technical essay. 
Pazwash H., 1983 Iran's Mode of Modernization: Greening the Desert, Deserting the Greenery Civil Engineering ASCE-ISSN 0360-0556, 53(3), 48-51.

Pirpiran M., 2007 History of water distribution in the Zayandehrood River and Sheikh Bahai's scroll. Paper presented at the International History Seminar on Irrigation and Drainage, Tehran, Iran, 2-5 May.

Schneier-Madanes G., Courel M.F., 2010. Water and sustainability in arid regions. High Demand in a Land of Water Scarcity: Iran, Zehtabian, G., H. Khosravi and M. Ghodsi (Eds.). Springer, London, New York, ISBN 13(9789048127757): 75-86.

Stiros S.C., 2006 Accurate measurements with primitive instruments: the "paradox" in the qanat design. Journal of Archaeological Science 33(8): 1058-1064

Voudouris K.S., Christodoulakos Y., Steiakakis E., Angelakis, A., 2013 Hydrogeological Characteristics of Hellenic Aqueducts-Like Qanats. Water (20734441), 5(3).

Wang, G., Zhu Y., 2012 Harmonization with Nature: Ancient Chinese Views and Technological Development. 357-377. In: Christensen, S. H., C. Mitcham, Li, B., An, Y., (Eds.) Engineering, development and philosophy: American, Chinese and European perspectives, Springer.

Wulff H.E., 1968 The Qanats of Iran. Scientific American, 94-105.

\section{$\underline{\text { Interviews }}$}

Moradmand, M., chief of the exploitation service of Qanats in Lenjan County, Isfahan, Iran, 20 January 2006.

Rajaei, M., chief of the local agricultural administration, Riz City, Isfahan, Iran, 28 January 2006. 
Local administration office of the Riz $2^{\text {nd }} \& 3^{\text {rd }}$ order irrigation networks, 21 November 2007.

Other interviews with the city council officers and local residents were conducted by the liaison officers of Payandab Tavan Consultant Engineering Co. in Iran, February 2006 (during the reconnaissance phase) and January 2007 (after the construction). 